\title{
Bertram Martin Wilson, M.A., D.Sc.
}

IT is with much regret that we record the death after a few weeks' illness, on March 18, 1935, of Bertram Martin Wilson, Professor of Mathematics in the University College, Dundee, in but the second year of his tenure of the Chair.

Wilson, who was born on November I4, I 896, was educated at King Edward School, Birmingham, and Trinity College, Cambridge, where he was Senior Scholar and a distinguished pupil of the school of mathematical analysts inspired by Hardy and Littlewood. After gaining high mathematical honours at Cambridge he went to the University of Liverpool in I920, and six years later became Senior Lecturer in Pure Mathematics. In I930 he married Margaret Fancourt Mitchell, and in I933 was elected to be Professor of Mathematics at Dundee, in the University of St Andrews, upon the retirement of Professor Steggall, the first occupant of the Chair. During the two short years of his life in Scotland, Wilson won the admiration and warm regard both of his colleagues and of his students. He willingly entered into the particular and also the broader duties of his office both in Dundee and in the University as a whole; and perhaps the students will best remember him for his love of music, which led him to co-operate actively in a scheme for arranging a notable series of musical recitals in the College.

Wilson, quiet and unassuming in demeanour, was a careful and brilliant expositor of mathematical analysis. He was not only a sound and lucid teacher of specialists, but he could on occasions give a thoroughly interesting account of an intricate subject to a general mathematical audience. His inaugural Dundee lecture on the Prime Number Theorem, as well as his lecture on Divergent Series to the Edinburgh Mathematical Society, will be remembered by his hearers as models of their kind. Besides producing many original papers he gave freely of his time to mathematical editorial work, and was chosen to be one of the three editors of the Compositio Mathematica, a recently founded international journal. But he will best be remembered for his part in the publication, in 1927, of the Collected Papers of $S$. Ramanujan, and more recently still for his elucidation of the labyrinth of arithmetical wonders left in the manuscript notebooks of that genius from India, a task which he undertook in collaboration with Professor G. N. Watson of Birmingham. 
Many hours of unstinted devotion were given to this work upon which Wilson was still engaged up to his illness. As a friend has said of him, we mourn the loss of a man of rare charm, taken from us in the spring of a career rich in promise.

He was elected a Fellow of the Society in 1934 .

H. W. T. 